\title{
RELIABILITY OPERATING PROVIDING OF THE ROAD CONSTRUCTION BY DETERMINING THE ACTUAL ELASTIC MODULUS
}

\section{ЗАБЕЗПЕЧЕННЯ ЕКСПЛУАТАЦІЙНОЇ НАДІЙНОСТІ АВТОМОБІЛЬНОЇ ДОРОГИ ШЛЯХОМ ВИЗНАЧЕННЯ ФАКТИЧНОГО МОДУЛЯ ПРУЖНОСТІ}

Fursovych M.A., PhD, senior teacher, Suprunyuk V.V., PhD, senior teacher, Ziatiuk Y.Y., PhD, senior teacher, Chepurko I.A. student (National University of Water and Environmental Engineering, Rivne)

Фурсович М.О., к.т.н., доцент, Супрунюк В.В., к.т.н., доцент, Зятюк Ю.Ю., к.т.н., доцент, Чепурко І.О., студентка (Національний університет водного господарства та природокористування м. Рівне)

The article discusses when applying the stamping method for the inspection of roads, it is possible to identify the actual modulus of elasticity of the structural layers of pavement and soil, to assess the homogeneity of materials, to determine the zones of local deviations in the soil. Materials of research of a technical resource of the highway, an unsatisfactory condition of its road clothes owing to its destruction are resulted.

Основною задачею мережі автомобільних доріг є рівномірний доступ до будь-якої точки на території країни. Автомобільні дороги повинні забезпечувати ефективні умови безпечного, безперервного, зручного пересування людей, та перевезення вантажів. Враховуючи постійний ріст навантажень і швидкості, загальної вантажопідйомності автомобілів $i$ їх кількості виникає потреба у будівництві нових доріг $і$ зберіганні існуючих доріг.

Асфальтобетон, щебінь, пісок, цемент, трунти та інші матеріали шарів покриття, які використовуються при будівництві автомобільних доріг, мають різні особливості роботи в дорожній конструкції. Всі матеріали по різному сприймають навантаження та силові впливи як стиск, зсув та розтяг. Оскільки асфальтобетон $\epsilon$ будівельним нелінійним в'язко-еластично-пластичним матеріалом, в основному складеним із ущільненої суміші щебеню, піску, мінерального порошку з бітумом, в значній мірі його властивості залежать від температури.

Незадовільний стан дорожнього одягу внаслідок руйнування автомобільної дороги є основним обмежувальним фактором технічного ресурсу дороги. В результаті контакту з конструкиією дорожнього покриття коліс транспортних засобів, яке здійснюється робочими навантаженнями на дорожне полотно, відбувається руйнування конструкиій дорожнього покриття, під дією багатьох чинників, основним з яких є експлуатаційне навантаження.

При застосуванні штампового методу для обстеження автомобільних доріг вдається виявити фактичний модуль пружності конструктивних шарів 
дорожнього одягу і грунтів земляного полотна, оцінити однорідність матеріалів, визначити в грунтах зони локальних відхилень. Наведено матеріали дослідження технічного ресурсу автомобільної дороги, незадовільний стан ї̈ дорожнього одягу внаслідок його руйнування.

Key words: longitudinal covering profile, rough-ness, strength of road coatings.

Ключові слова: профіль покриття, рівність, міџність дорожнього одягу.

Introduction. Experience in the operation of roads shows that the stage of their destruction, which consists of the occurrence and development of cracks, begins long before the load-bearing capacity of the road is exhausted. This may occur due to non-compliance with the requirements of structural parameters laid down in the design of the road, violation of construction technology, the impact of environmental factors, a complex stress-strain state in the road and so on. At the same time, during the destruction, not only the structural strength of the road is not exhausted, but also the strength of individual structural layers [1,2].

The vast majority of Ukrainian roads were built in the 60's and 80's of the last century in accordance with the standards and requirements in force at that time. Due to the growing characteristics of vehicles, the design of pavement is unable to withstand the dynamic loads that occur during the movement of modern vehicles [3].

The main limiting factor of the technical resource of the road is the unsatisfactory condition of its pavement due to its destruction. The destruction of road structures occurs under the influence of many factors, the main of which is the operational factor due to the workload on the roadway as a result of contact with the wheels of vehicles. In the area of contact of the wheels with the surface of the pavement there is a complex stress-strain state, complicated by dynamic loading [4,5].

The task of studying the operational condition of pavement in the planning of repair and restoration works of roads is to collect and analyze information about the condition of pavement in terms of transport and operational indicators and strength characteristics for compliance with operating conditions.

Special specificity in the work of the road structure is made by the materials of the coating layers, which include bituminous concrete, cement, rubble chippings, sand, soil, etc. [6, 7]. All of them are differently resistant to tension, compression and shear, and bituminous concrete, in addition, in the general case, is a nonlinear visco-elastic-plastic material, the properties of which largely depend on temperature $[8,9]$.

Determination of operational reliability of the highway is carried out by collecting data on the following indicators and parameters [10]:

- information about the road, geometric parameters of the highway;

- characteristics of traffic on the road (load, its size, quantity); 
- characteristics of pavement and coating (thickness of layers, modulus of elasticity of each layer, total modulus of elasticity of the structure, vertical stresses in the structural layers, the size of the deflection bowl);

- subgrade soil characteristics (modulus of elasticity; humidity, vertical stresses in the core, the degree of compaction of the core soil);

- weather and climatic conditions (humidity, air temperature, coating temperature);

- forecasting changes in the characteristics of roads and development of recommendations for improving transport and operational performance.

Causes of destruction:

potholes - local destruction of the coating with a depth of 20 to $150 \mathrm{~mm}$ and more with sharply outlined edges. They occur primarily due to insufficient bonds between mineral and organic materials, undercompaction of the coating, the use of poor quality materials (overheating of the asphalt mixture, the ingress of untreated gravel into the mixture, etc.). The process of pothole formation is especially active during the rainy season, which is facilitated by daily fluctuations in air temperature and coverage, the presence of water in the pores of the coating. Penetrating into the shells and microcracks of the coating, water has a wedging effect. The bond between the particles of material weakens and under the influence of the car's wheels a hole is formed, which can increase rapidly.

longitudinal cracks - located in 20-40 cm from each other on the rolling strips, in combination with transverse cracks in 1-4 $\mathrm{m}$ on the entire width of the roadway. They are formed during heavy transport loads due to insufficient strength of individual layers of clothing and soil base, excess loads and traffic intensity compared to the calculated values;

transverse cracks - cracks with uneven edges across the width of the coating. Arise as a result of air temperature difference and insufficient resistance to temperature tension. They are located on the roadway at an appropriate distance from each other (5-10 m);

reflected cracks - cracks that reflect the located cracks in the structure of the pavement below. The reflected cracks can be located in different directions.

net cracks - a cracked coating that resembles a mosaic or crocodile skin. net cracks is a set of polygons. Delayed repair work can lead to the formation of potholes or significant deformation. In places of deepening water delayed, then it gets under the pavement. Causes: insufficient load-bearing capacity due to soil moisture, poor drainage, under-compaction of the base layers or the ground.

chipping - occurs due to the loss of individual grains of mineral material and is associated with the loss of bond between the grains of the material.

As sections of roads for the study were selected sections of roads with different state of coverage from $150 \mathrm{~m}$ to $800 \mathrm{~m}$.

Coating tests were performed on the following sections of roads: 

$\mathrm{km}$;

P-77 Rivne - Tuchyn - Goshcha - Velbivno from $2+000 \mathrm{~km}$ to $2+800$

- P-62 Kryvorivnya - Chernivtsi PC $51+27-$ PC $82+20$;

- P-62 Kryvorivnya - Chernivtsi $15+000 \mathrm{~km}$ to $15+800 \mathrm{~km}$;

$-\mathrm{H}-22$ Ustyluh - Lutsk - Rivne from $11+000 \mathrm{~km}$ to $11+800 \mathrm{~km}$.

\section{Experimental studies}

We will test device for determining the carrying capacity of 35-T0116 / C "CONTROLS" according to the instructions. [5]

Loads on the surface of the tested structure are transmitted through a round rigid stamp with a jack resting on the frame of the loaded car (Fig. 1,). The load on the stamp is measured using a dynamometer built into the jack. The vertical movement of the stamp is fixed by the movement indicator of the clock type, the measuring rod of which is installed in the center of the stamp. In this case, the jack on the three support struts is installed on the stamp. The indicators are securely fastened to the rigid rail.

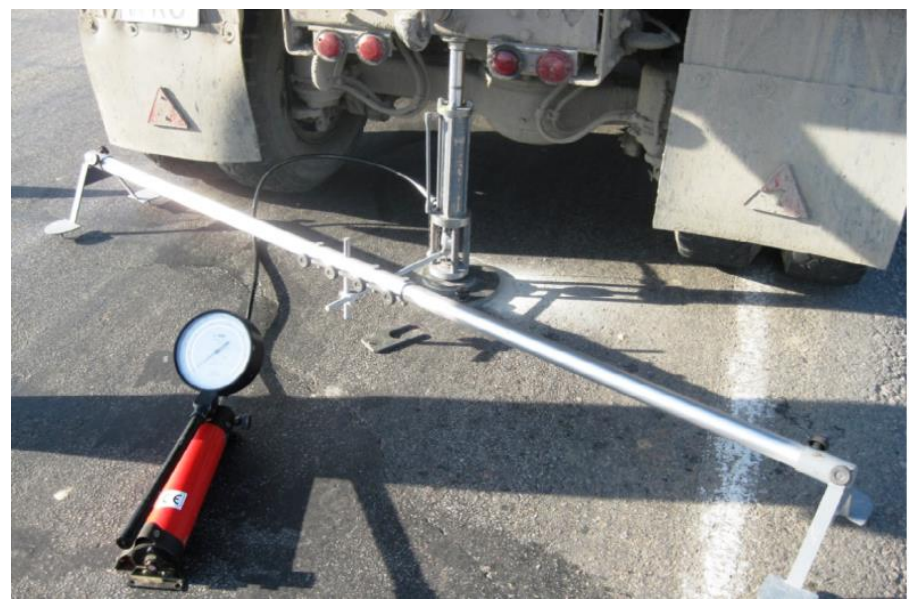

Fig. 1. Type of testing of pavement by stamping method device 35-T0116/ C "CONTROLS"

The load during the test is applied in levels to the maximum calculated value of $0.5 \mathrm{MPa}$; in total there should be not less than $3-6$ levels. Load holding time - $60 \mathrm{~s}$, pauses after unloading - $60 \mathrm{~s}$, for loading and unloading - 20 $-30 \mathrm{~s}$. 
The research results - the modulus of elasticity of the soil or material in a homogeneous structure, as well as the total modulus of elasticity of the layered structure, tested by loads with a rigid stamp, are calculated by the formula:

$$
E_{y}=0,25 \pi \rho D\left(1-\mu^{2}\right) / l
$$

where $p$ is the maximum (calculated) pressure from the stamp, MPa;

$D$ is the diameter of the rigid stamp, $\mathrm{cm}$;

$\mu$ - Poisson's ratio (for soils $\mu=0.35$, for base materials $\mu=0.25$, and when calculating the total modulus of elasticity $\mu=0.3) ; l$ - is the elastic deformation corresponding to this load, $\mathrm{cm}$.

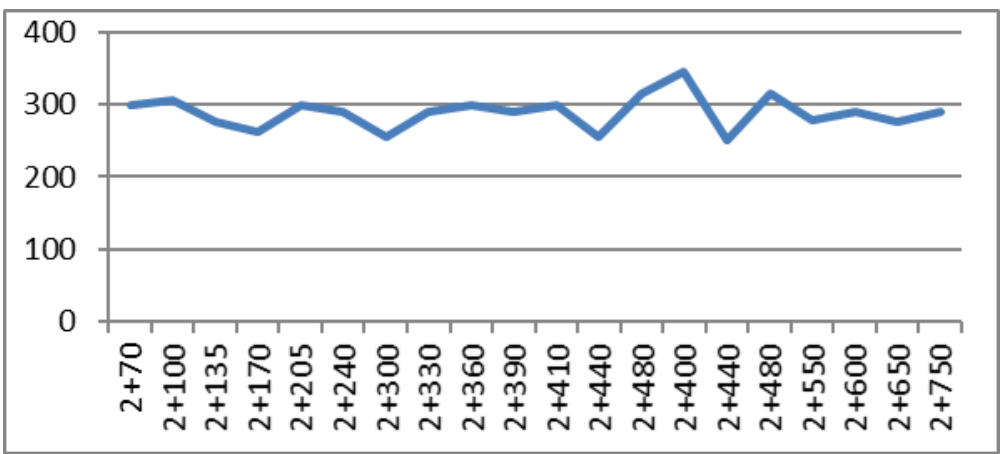

Fig. 2. Change of the modulus of elasticity of road pavement on the study area № 1

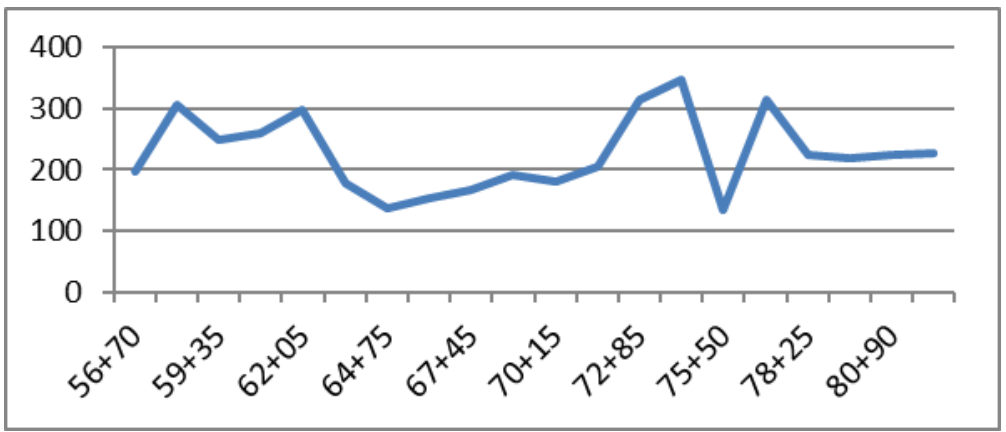

Fig. 3. Change of the modulus of elasticity of road pavement on the study area № 2 


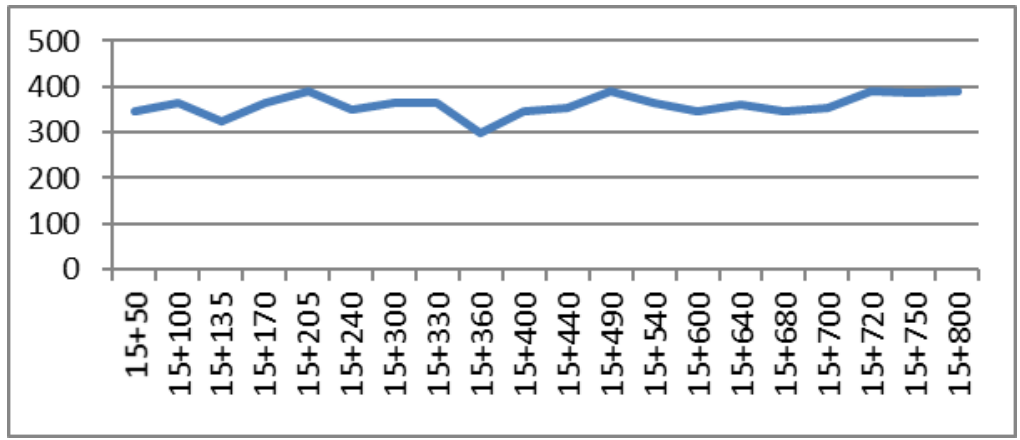

Fig. 4. Change of the modulus of elasticity of road pavement on the study area № 3

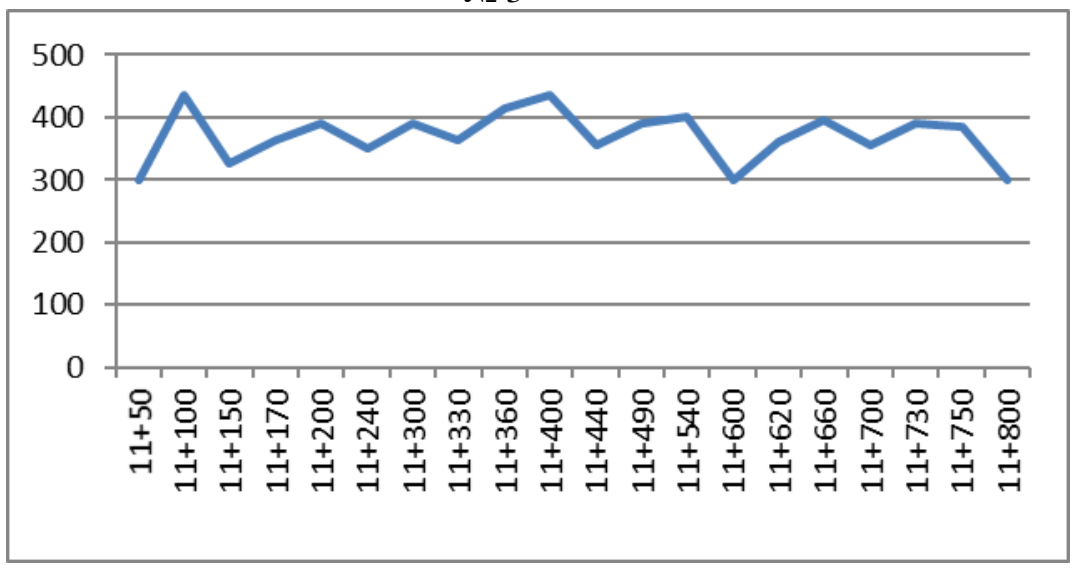

Fig. 5. Change of the modulus of elasticity of road pavement on the study area № 4

\section{Conclusions}

1. On the pavement in the process of operation, under the action of vehicles in the surface layers of the pavement, that is in the zone of concentration of contact stresses, there is the formation of potholes, accumulate irregularities that significantly worsen the transport and operational performance of roads. The most common damages are: potholes, longitudinal cracks, transverse cracks, chipping.

2. When using the stamping method for the inspection of roads, it is possible to identify the actual modulus of elasticity of the structural layers of pavement and soil, to assess the homogeneity of materials, to determine the zones of local deviations in the soil.

3. The method of stamp tests significantly increases the reliability of road structures by increasing the reliability of information, the obtained parameters of 
coverage in the future will calculate the value of the dynamic load on the pavement.

Thanks to objective data on the strength of the natural base and structural layers of the road surface, design engineers can identify and apply the necessary measures to increase the strength and deformation characteristics of the structure. Testing, with further adjustment of the existing project, will save material, construction time, timely monitor the quality of work and thus obtain a reliable and economical design of the foundation during its operation.

\section{References}

1. Hamelyak Ihor Pavlovych. Osnovy zabezpechennya nadiynosti konstruktsiy dorozhn'oho odyahu: dis ... Dr. Tech. Sciences: 05.22.11 / National Transport University. - K., 2005.

2. Dmytrychenko M.F., Dmytriyev M.M., Hamelyak I.P., Raykovs'kyy V.F., Yakymenko YA.M. Nadiynist' konstruktsiy dorozhn'oho odyahu. - Teaching. manual. K $\therefore$ NTU. - 2012. - 206 p.

3. Leonovich I.I., Bogdanovich S.V., Nesterovich I.V. Diagnostika avtomobil'nykh dorog: ucheb. posobiye. Minsk: "New knowledge", 2011.350 p.

4. Sil'yanov V.V., Domke E.R. Transportno-ekspluatatsionnyye kachestva avtomobil'nykh dorog i gorodskikh ulits: textbook. allowance. Moscow: Academy, 2008. $348 \mathrm{p}$.

5. Kochetkov A.V., Belyayev D.S., Shashkov I.G. Pryamoy metod otsenki vzaimodeystviya kolesa transportnogo sredstva i nerovnostey dorozhnogo pokrytiya. Internet magazine "Science of Science". 2013. No. 4 (17). P. 38-55.

6. Madanat S., Prozzi J.A., Han M.: Effect of Performance Model Accuracy on Optimal Pavement Design. Computer-aided Civil and Infrastructure Engineering. 17, 1, 2002, 22-30 https://trid.trb.org/view/709481 14.12.2020.

7. Huang Y.H.: Pavement Analysis and Design Pearson Education. Upper Saddle River, NJ, USA, 2004.

8. SOU 45.2-00018112-078:2012 Avtomobil'ni dorohy. Otsinka rivnosti dorozhnikh pokryttiv za Mizhnarodnym Indeksom Rivnosti (IRI) / Kyiv, State Road Service of Ukraine, 2012. $32 \mathrm{p}$.

9. SOU 45.2-00018112-042:2009. "Avtomobil'ni dorohy. Vyznachennya transportno-ekspluatatsiynykh pokaznykiv dorozhnikh odyahiv". - Kharkiv: KhNADU. 2009. $42 \mathrm{p}$.

10. Modeling Road Deterioration and Maintenance Effects in HDM-4. RETA 5549-REG Highway Development and Management Research, Final Report. Prepared for Asian Development Bank by N.D. Lea International Ltd, October, 1995, 351p. http://www.lpcb.org/index.php/edocman-test/1995-modelling-road-deterioration-andmain tenance-effects-in-hdm-4/viewdocument 14.12.2020.

11. Plate bearing test apparatus mod. 35-T0116/C "CONTROLS". Instruction manual. West Conshohocken, PA: ASTM International, 2015. 5 p. 